\title{
SADAR HUKUM, SADAR WIRAUSAHA DAN SADAR LINGKUNGAN BAGI PEMBERDAYAAN MASYARAKAT PESISIR TANJUNGPASIR
}

\author{
Oleh: \\ Endang Purwaningsih, \\ Nurul Huda, \\ Abdul Salam M. Sofro \\ Sekolah Pascasarjana Universitas YARSI, Jakarta \\ Email: endang.purwaningsih@yarsi.ac.id
}

\begin{abstract}
ABSTRAK
Masalah inti yang disikapi adalah upaya pemberdayaan yang dapat dilakukan terhadap masyarakat Tanjung Pasir terkait upaya menumbuhkembangkan sadar hukum, sadar wira usaha, dan sadar lingkungan dan model pemberdayaan masyarakat pesisir yang tepat untuk diterapkan pada masyarakat TanjungPasir agar warga masyarakat sasaran memperoleh wawasan pengetahuan dan keterampilan tentang hukum, wira usaha dan lingkungan, sehingga memberi daya dukung bagi tumbuhnya pemberdayaan berdasarkan pendekatan partisipatif. Tujuan kegiatan ini adalah agar warga masyarakat mendapatkan perannya dan diwadahi aspirasinya dalam pembentukan model pemberdayaan yang akan bisa diterapkan untuk masyarakat pesisir Tanjungpasir, sekaligus sebagai prototipe bagi pemberdayaan masyarakat pesisir (pada tahun berikutnya/skim lain). Kegiatan ini dilaksanakan dengan menggunakan metode ceramah dan metode pelatihan. Dalam upaya memberdayakan masyarakat Tanjung Pasir terkait upaya menumbuhkembangkan sadar hukum, sadar wira usaha, dan sadar lingkungan perlu didampingi dan diberikan uluran tangan serta perhatian dari pemerintah, kampus dan LSM serta partisipasi aktif warga sendiri. Model pemberdayaan yang tepat untuk diterapkan pada masyarakat pesisir, adalah dengan kerjasama sinergitas antara warga masyarakat, aparat desa, dinas terkait serta LSM yang peduli serta bantuan kampus. Pemberdayaan pada tahap awal ini penting untuk menumbuhkan kesadaran tentang hukum, wira usaha, dan lingkungan, mengingat pada dasarnya pemahaman warga masyarakat terhadap pengelolaan sampah sudah bagus, wira usaha cukup paham, namun pemahaman tentang hukum sangat rendah.
\end{abstract}

Kata kunci: Sadar Hukum, Sadar Wirausaha, Sadar Lingkungan, Pemberdayaan

Masyarakat

\section{ABSTRACT}

The core problems which should be anticipated in Tanjung Pasir are the people's poor legal awareness, their lack of reliable entrepreneurship, and their moderate concern about environment. And the most suitable empowerment model to meet these challenges seems to be the participative approach. A program has then been set up to enable the local people to gain their roles and to accommodate their 
aspiration. This program-a prototype for the next project (in the following year/another scheme)—should serve as an empowerment model for coastal communities. Using lecturing and training methods, this program should be able to promote legal awareness, nourish entrepreneurship, and improve concern about environment among people in Tanjung Pasir. And to achieve these objectives, concern from the local government, academic society, NGOs, and the local people themselves is a must. This means building synergy among the local people, local apparatus, related authorities, NGOs, and academic people. Such empowerment at this initial stage is crucial since these people already have moderate concern about environment-indicated by sufficient waste-management skills-and adequate entrepreneurship yet still possess poor legal awareness.

Keywords: Legal Awareness, Entrepreneurship Awareness, Environmental Awareness, Community Empowerment

\section{PENDAHULUAN}

Sebenarnya Kabupaten Tangerang Banten mempunyai potensi bahari dengan garis pantai Utara-nya yang panjangnya berkisar $50 \mathrm{KM}$, dari Pantai Dadap sampai Pantai Kronjo, meliputi 7 kecamatan: Kosambi, Teluk Naga, Paku Haji, Kronjo, Sukadiri, Kemiri dan Mauk. Salah satu kawasan wisata bahari yang cukup ramai dikunjungi orang saat liburan, baik liburan akhir pekan atau liburan nasional lainnya, adalah Pantai Tanjung Pasir, yang masuk wilayah kecamatan Teluk Naga. Menuju ke Pantai Tanjung Pasir, yang jaraknya berkisar +/- 29 KM dari Kota Tangerang atau +/- $25 \mathrm{KM}$ dari exit pintu M-1 (west gate) Bandara Soekarno Hatta, melalui jalan Marsekal Surya Darma (Jalan Selapanjang),papan nama Selamat Datang di Kawasan Wisata Tanjung Pasir. Di balik gemerlapnya pantai, di situ pula bermunculan warung remang prostitusi, kantong kemiskinan dan gizi buruk. Perkawinan dini juga menjadi pemicu dari hal-hal negatif tersebut.

Desa Sejahtera hasil binaan Solidaritas Istri Kabinet Indonesia Bersatu (SIKIB) di Desa Tanjung Pasir, Tangerang, Banten juga telah dicanangkan, akan tetapi perguruan tinggi perlu menurunkan Tim Relawannya sebagai bentuk kepedulian sosial kepada masyarakat dalam bentuk pengabdian kepada masyarakat. Masyarakat pesisir mengalami berbagai masalah, seperti persoalan kemiskinan, pendidikan rendah, kesadaran hukum dan berwirausaha juga rendah, yang berujung pada buruknya kesehatan dan tingkat ekonomi. Masyarakat ini perlu dibina dengan tindakan pemberdayaan yang berkelanjutan. Seperti halnya 
kebanyakan masyarakat pesisir, maka warga Tanjungpasir bekerja sebagai nelayan yang jumlah penghasilannya tidak menentu. Penduduk memiliki karakter yang berbeda-beda. Kebanyakan penduduk melakukan perkawinan dini masih memiliki anak lebih dari 2 balita, dikarenakan tidak mengikuti program Keluarga Berencana. Pekerjaan ibu-ibu sebagian besar adalah membantu suaminya dan waktu luangnya hanyalah main ke tetangga. Pekerjaan Bapak-bapak kebanyakan juga nelayan tradisional, buruh nelayan, bahkan banyak yang tidak produktif karena tidak punya perahu sendiri. Terdapat kantong kemiskinan dan kurang terfasilitasinya kesehatan dengan baik, sehingga anak-anak tidak terjamin baik dalam pendidikan, gizi dan kesehatan. Masyarakat hanya mencari ikan dan belum ada usulan ataupun uluran tangan pemerintah untuk berwirausaha yang lebih produktif, baik untuk mengisi waktu senggang suami, maupun untuk kegiatan sehari-hari istri di rumah.

Permasalahan yang dihadapi oleh Aparat Desa Tanjungpasir Tangerang adalah:

a. Kurangnya pengetahuan dan kesadaran akan pentingnya lingkungan yang sehat baik dalam lingkup keluarga maupun masyarakat

b. Kurangnya kesadaran akan pentingnya berbisnis serta wira usaha di daerah yang potensial untuk bisnis

c. Kurangnya kesadaran akan hukum (perkawinan, perlindungan anak, perceraian) Kurangnya perhatian pemerintah secara berkelanjutan dalam menumbuhkan semangat wirausaha, penyadaran masyarakat yang kurang, dan pola pikir masyarakat belum sadar tentang kemiskinan, rawan gizi dan rawan tindak kejahatan

d. Terbatasnya Sumber Daya Manusia yang akan menjadi penyuluh /pendidik bagi ibu-ibu agar ber-KB, juga terhadap bapak-bapak dan menyumbang perekonomian keluarga melalui wirausaha

e. Kurangnya lapangan dan fasilitas yang memadai untuk menampung pengangguran (apalagi dengan UMR)

f. Kurangnya motivasi dan uluran tangan dari perguruan tinggi atau pun LSM untuk berwirausaha dan bantuan modal peralatan 
Berdasarkan analisis situasi dan identifikasi masalah di atas, maka dapat dirumuskan permasalahan sasaran yang disikapi sebagai berikut.

a. Bagaimanakah upaya pemberdayaan dilakukan terhadap masyarakat Tanjung Pasir terkait upaya menumbuhkembangkan sadar hukum, sadar wira usaha, dan sadar lingkungan?

b. Bagaimanakah model pemberdayaan masyarakat pesisir yang tepat untuk diterapkan pada masyarakat TanjungPasir?

Hasil kegiatan ini diharapkan dapat memberikan manfaat berupa meningkatnya pengetahuan, keterampilan dan kesadaran masyarakat khususnya dalam memecahkan berbagai masalah yang sering ditemukan dalam kehidupan sehari-hari tentang hukum, wira usaha dan lingkungan sehingga memberi daya dukung bagi tumbuhnya pemberdayaan berdasarkan pendekatan partisipatif dan terciptanya pembentukan model pemberdayaan yang akan bisa diterapkan untuk masyarakat pesisir sekaligus sebagai prototipe.

\section{METODE}

Kegiatan ini dilaksananakan bekerja sama dengan aparat Desa Tanjung Pasir dan pengelola rumah pintar. Secara kualitatif kegiatan ini sebagai upaya awal terbentuknya kader-kader wirausaha baru sebagai contoh panutan keluarga Harapan (menuju) Sejahtera, sadar wirausaha, sadar lingkungan dan Kadarkum, juga terbentuknya jaringan kerjasama yang baik antara Universitas Yarsi, masyarakat dalam pencegahan dan penanggulangan kejahatan dan upaya penyadarannya.

Kegiatan ini dilaksanakan dengan menggunakan metode-metode berikut:

1. Metode ceramah

Metode ini digunakan untuk menyampaikan materi penyuluhan yang bersifat kognitif seperti dalam pembentukan sadar hukum, wira usaha dan sadar lingkungan. Pelaksanaan metode ini digunakan waktu sebanyak $40 \%$ untuk ceramah atau penyampaian materi, sedangkan sisanya $60 \%$ digunakan untuk diskusi dan tanya jawab. 


\section{Metode Pelatihan}

Dalam metode ini, kegiatan utama yang akan dilaksanakan adalah pembimbingan dan pelatihan bagi para peserta untuk membuat atau meningkatkan keterampilan yang sudah dikuasainya. Pendekatan yang dilakukan antara lain: Penyuluhan dan aplikasi lapangan berupa pengayaan materi serta keterampilan untuk kewirausahaan dan bantuan hukum (pendampingan) jika sasaran terlibat masalah hukum. Tim SPS UY juga menggali informasi sebanyak mungkin mengenai kerjasama yang telah terbina dengan SIKIB dan realisasinya, agar dapat dilanjutkan menuju arah yang lebih terprogram dan lebih bermanfaat bagi masyarakat Tanjungpasir.

\section{PEMBAHASAN}

Memberdayakan adalah merupakan suatu proses yang dilakukan oleh Pemerintah dan/atau kelompok berbasis komunitas untuk mengelola sekaligus melindungi hak-haknya. Salah satu strategi yang dapat dikembangkan dalam memberdayakan masyarakat dalam mengelola dan melindungi adalah dengan konsep partisipatif. Pemberdayaan masyarakat dengan pendekatan partisipatif diarahkan untuk mengelola sekaligus melindungi hak yang dimilikinya.

Secara konseptual pemberdayaan masyarakat dengan pendekatan partisipatif dapat dijelaskan: i) pemetaan potensi wilayah, yang meliputi potensi SDA, SDM, kondisi sosial budaya, ketersediaan sarana prasarana sosial ekonomi serta potensi perekonomian, ii) melakukan analisis dari hasil pemetaan potensi untuk menentukan beberapa alternatif pengembangan usaha, iii) analisis kelayakan dari berbagai pilihan usaha yang telah ditetapkan sebagai dasar dalam menentukan usaha yang akan dijadikan fokus (usaha inti), usaha pendukung, usaha terkait, usaha hulu dan hilir serta lembaga-lembaga yang akan melakukan support pada pengembangan usaha, iv) output yang diharapkan dengan konsep ini adalah penyerapan tenaga kerja, pertumbuhan ekonomi wilayah, pertumbuhan investasi dan penurunan angka kemiskinan (Soenyono, 2007).

Sejalan dengan konsep pemberdayaan, maka diharapkan dengan kegiatan ini warga masyarakat sasaran memperoleh wawasan pengetahuan dan keterampilan tentang hukum, wira usaha dan lingkungan sehingga memberi daya 
dukung bagi tumbuhnya pemberdayaan berdasarkan pendekatan partisipatif, juga masyarakat mendapatkan perannya dan diwadahi aspirasinya dalam pembentukan model pemberdayaan yang akan bisa diterapkan untuk masyarakat pesisir Tanjungpasir sekaligus sebagai prototipe bagi pemberdayaan masyarakat pesisir.

Kegiatan dilakukan dengan sinergitas antara warga dan para pengabdi juga aparat desa dan pengelola rumah pintar Tanjung Pasir. Kegiatan dimulai dengan penjajagan dan administrasi dengan berkunjung ke kantor desa dan diterima dengan baik oleh aparat (staf). Kepala desa sendiri beberapa kali dihubungi tetap tidak ada konektivitas. Sampai kegiatan ini usai, para pengabdi belum pernah bertemu dnegan Kepala Desa Tanjung Pasir. Wawancara dan pengamatan sebagai pendukung kuesioner langsung kepada sekretaris desa dan pengelola rumah pintar. Kuesioner dan pelatihan serta penyuluhan hukum dilaksanakan di rumah pintar.

Pada dasarnya pemahaman warga masyarakat terhadap pengelolaan sampah sudah bagus, wira usaha cukup paham, dan pemahaman tentang hukum sangat rendah. Adapun rinciannya sebagai berikut.

\section{Aspek Hukum}

Peserta pengabdian sebanyak 25 peserta tetapi isian kuesioner yang dapat diolah sebanyak 23 peserta. Kuesioner untuk aspek hukum memiliki 5 pertanyaan dengan hasil sebagai berikut.

1. Apa saudara paham apa yang dimaksud dengan hukum, terkait pertanyaan ini maka peserta menjawab seperti terlihat dalam tabel di bawah ini :

Tabel 1. Aspek Hukum 1

\begin{tabular}{|rr|r|r|r|r|}
\hline & Frequency & Percent & Valid Percent & $\begin{array}{c}\text { Cumulative } \\
\text { Percent }\end{array}$ \\
\hline Valid 1.00 & 1 & 4.3 & 4.3 & 4.3 \\
& 2.00 & 10 & 43.5 & 43.5 & 47.8 \\
3.00 & 6 & 26.1 & 26.1 & 73.9 \\
4.00 & 6 & 26.1 & 26.1 & 100.0 \\
Total & 23 & 100.0 & 100.0 & \\
\hline
\end{tabular}

Sumber : Kuesioner, data diolah 


\section{Pemahaman ttg apa yang dimaksud dengan}

hukum

घ1 $\approx 2=3 \approx 4$

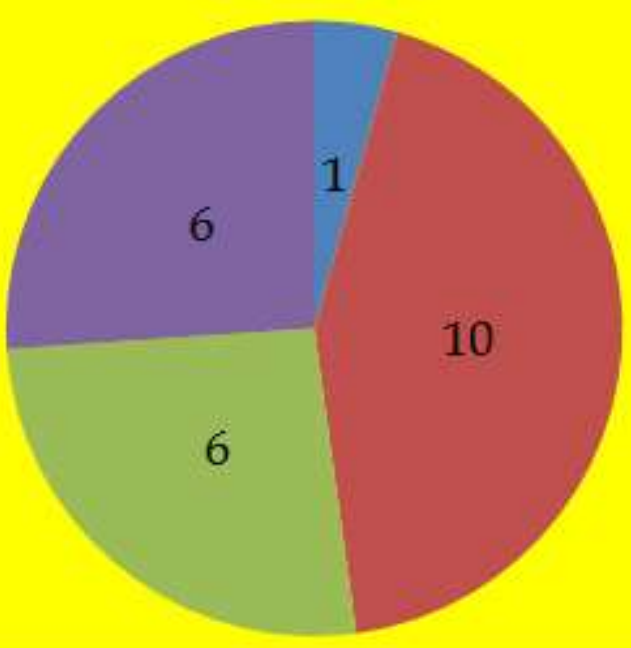

Berdasarkan tabel di atas $43,5 \%$ peserta tidak paham apa yang dimaksud dengan hukum sedangkan yang paham dan cukup paham memiliki persentase yang sama yaitu $26,1 \%$. Peserta yang menjawab sangat tidak paham sebesar $4,3 \%$.

2. Apa saudara paham dengan penegakan hukum? terkait pertanyaan ini maka peserta menjawab seperti terlihat dalam tabel di bawah ini :

Tabel 2. Aspek Hukum 2

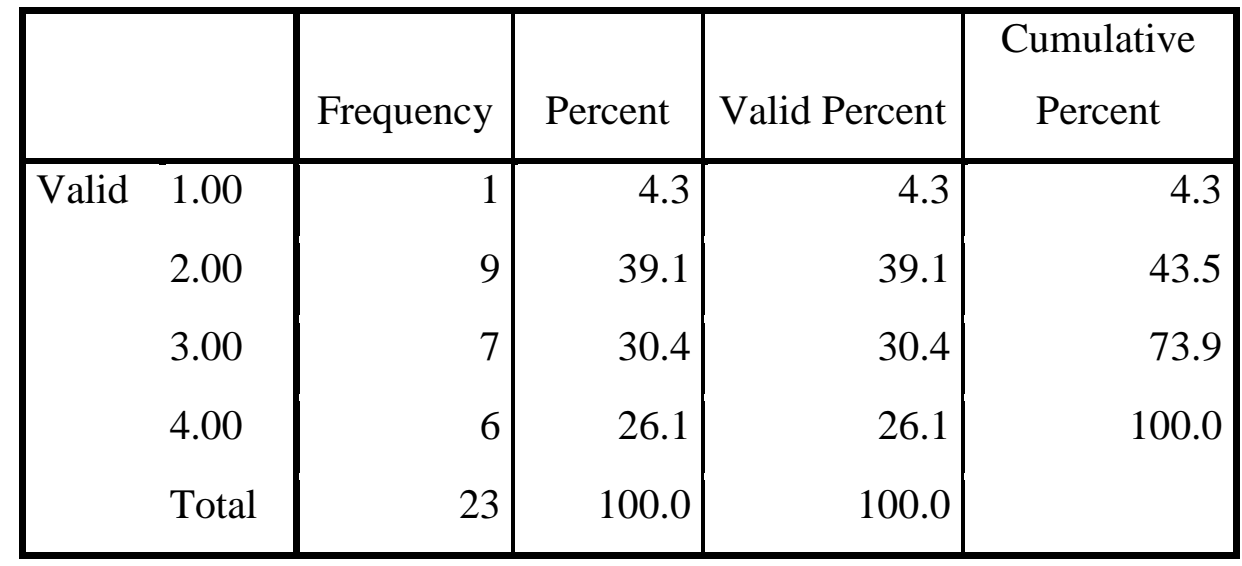

Sumber : Kuesioner, data diolah 


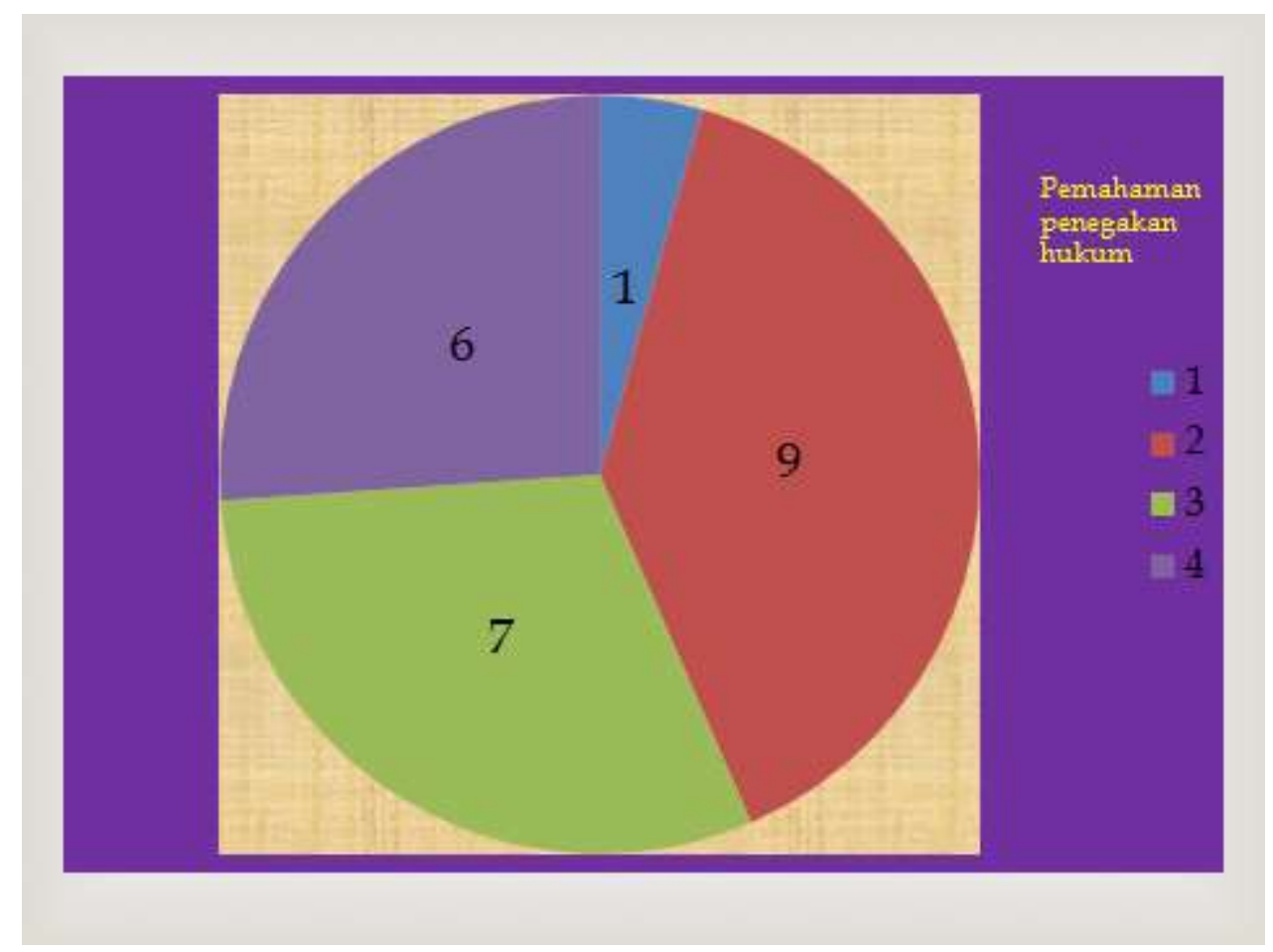

Berdasarkan tabel di atas 39,1 \% peserta tidak paham apa yang dimaksud dengan penegakan hukum sedangkan yang paham dan cukup paham memiliki persentase masing-masing yaitu $26,1 \%$ dan $30,4 \%$. Peserta yang menjawab sangat tidak paham sebesar $4,3 \%$.

3. Apa saudara paham dengan perlindungan hukum? terkait pertanyaan ini maka peserta menjawab seperti terlihat dalam table di bawah ini :

Tabel 3. Aspek Hukum 3

\begin{tabular}{|r|r|r|r|r|}
\hline & Frequency & Percent & Valid Percent & $\begin{array}{c}\text { Cumulative } \\
\text { Percent }\end{array}$ \\
\hline Valid 2.00 & 10 & 43.5 & 43.5 & 43.5 \\
& 3.00 & 13.0 & 13.0 & 56.5 \\
4.00 & 10 & 43.5 & 43.5 & 100.0 \\
& 23 & 100.0 & 100.0 & \\
\hline
\end{tabular}

Sumber : Kuesioner, data diolah 


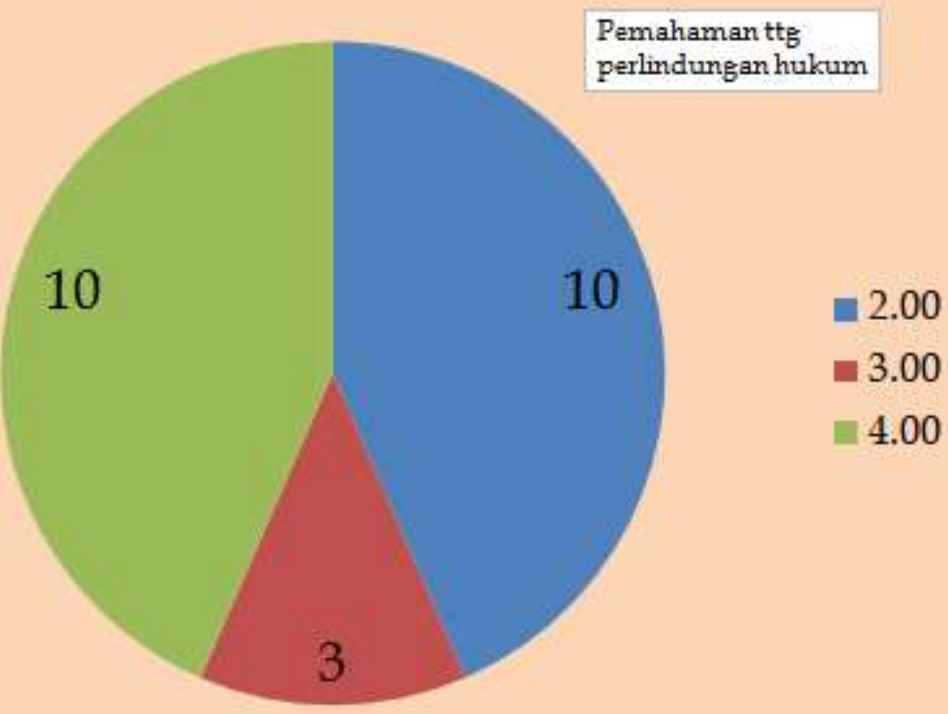

Berdasarkan tabel di atas $43,5 \%$ peserta tidak paham apa yang dimaksud dengan perlindungan hukum sedangkan yang paham dan cukup paham memiliki persentase masing-masing yaitu $43,5 \%$ dan $13,0 \%$. Peserta yang menjawab sangat tidak paham tidak ada.

4. Apa saudara paham tentang bagaimana perlindungan hukum terhadap transaksi bisnis? terkait pertanyaan ini maka peserta menjawab seperti terlihat dalam table di bawah ini :

Tabel 4. Aspek Hukum 4

\begin{tabular}{|r|r|r|r|r|}
\hline & Frequency & Percent & Valid Percent & $\begin{array}{c}\text { Cumulative } \\
\text { Percent }\end{array}$ \\
\hline Valid 2.00 & 15 & 65.2 & 65.2 & 65.2 \\
& 3.00 & 13.0 & 13.0 & 78.3 \\
4.00 & 3 & 13.0 & 13.0 & 91.3 \\
5.00 & 2 & 8.7 & 8.7 & 100.0 \\
Total & 23 & 100.0 & 100.0 & \\
\hline
\end{tabular}

Sumber : Kuesioner, data diolah 


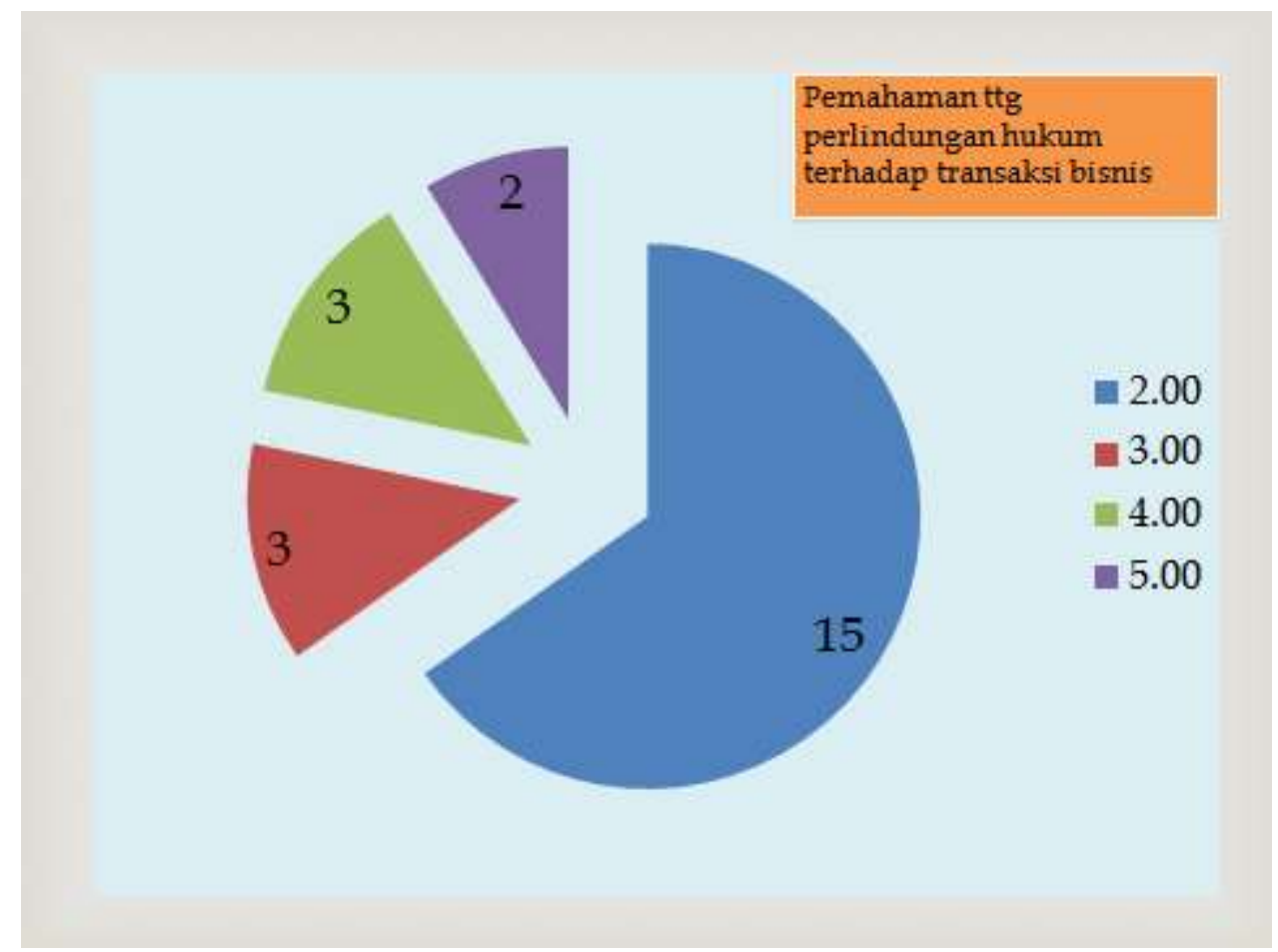

Berdasarkan tabel di atas $65,2 \%$ peserta tidak paham apa yang dimaksud dengan perlindungan hukum terhadap transaksi bisnis sedangkan yang paham dan cukup paham memiliki persentase yang sama yaitu $13,0 \%$. Peserta yang menjawab sangat paham sebesar $8,7 \%$.

5. Apa saudara paham tentang upaya hukum jika perjanjian dilanggar ? terkait pertanyaan ini maka peserta menjawab seperti terlihat dalam table di bawah ini :

Tabel 5. Aspek Hukum 5

\begin{tabular}{|r|r|r|r|r|}
\hline & Frequency & Percent & Valid Percent & \multicolumn{2}{c|}{\begin{tabular}{c} 
Percent \\
\hline Valid 1.00
\end{tabular}} & 1 & 4.3 & 4.3 & 4.3 \\
& 10 & 43.5 & 43.5 & 47.8 \\
3.00 & 4 & 17.4 & 17.4 & 65.2 \\
4.00 & 6 & 26.1 & 26.1 & 91.3 \\
5.00 & 2 & 8.7 & 8.7 & 100.0 \\
Total & 23 & 100.0 & 100.0 & \\
\hline
\end{tabular}

Sumber : Kuesioner, data diolah 


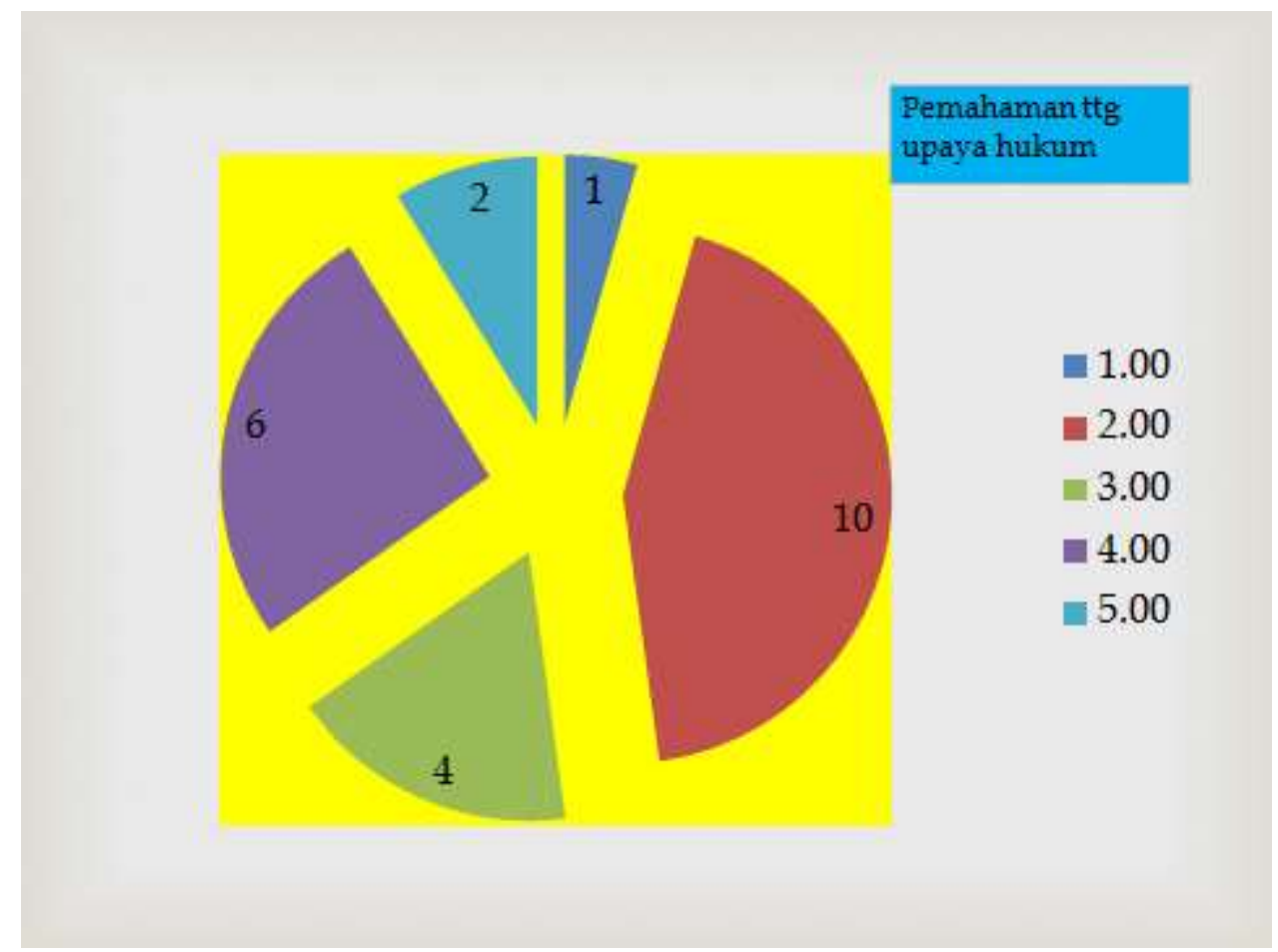

Berdasarkan tabel di atas 43,5 \% peserta tidak paham apa yang dimaksud dengan upaya hukum jika perjanjian dilanggar sedangkan yang paham dan cukup paham memiliki persentase yang sama yaitu 26,1\%. Peserta yang menjawab sangat paham sebesar $8,7 \%$. Sedangkan peserta yang sangat tidak paham sebesar $4,3 \%$.

\section{Aspek Kewirausahaan}

Kuesioner untuk aspek kewirausahaan memiliki 5 pertanyaan dengan hasil sebagai berikut:

1. Apakah saudara paham arti kewirausahaan? terkait pertanyaan ini maka peserta menjawab seperti terlihat dalam table di bawah ini :

Tabel 6. Wirausaha 1

\begin{tabular}{|c|c|c|c|c|c|}
\hline & & Frequency & Percent & Valid Percent & $\begin{array}{c}\text { Cumulative } \\
\text { Percent }\end{array}$ \\
\hline \multirow[t]{4}{*}{ Valid } & 2.00 & 4 & 17.4 & 17.4 & 17.4 \\
\hline & 3.00 & 7 & 30.4 & 30.4 & 47.8 \\
\hline & 4.00 & 9 & 39.1 & 39.1 & 87.0 \\
\hline & 5.00 & 3 & 13.0 & 13.0 & 100.0 \\
\hline
\end{tabular}


Tabel 6. Wirausaha 1

\begin{tabular}{|r|r|r|r|r|}
\hline & Frequency & Percent & Valid Percent & $\begin{array}{c}\text { Cumulative } \\
\text { Percent }\end{array}$ \\
\hline Valid 2.00 & 4 & 17.4 & 17.4 & 17.4 \\
3.00 & 7 & 30.4 & 30.4 & 47.8 \\
4.00 & 9 & 39.1 & 39.1 & 87.0 \\
5.00 & 3 & 13.0 & 13.0 & 100.0 \\
\hline Total & 23 & 100.0 & 100.0 & \\
\hline
\end{tabular}

Sumber : Kuesioner, data diolah

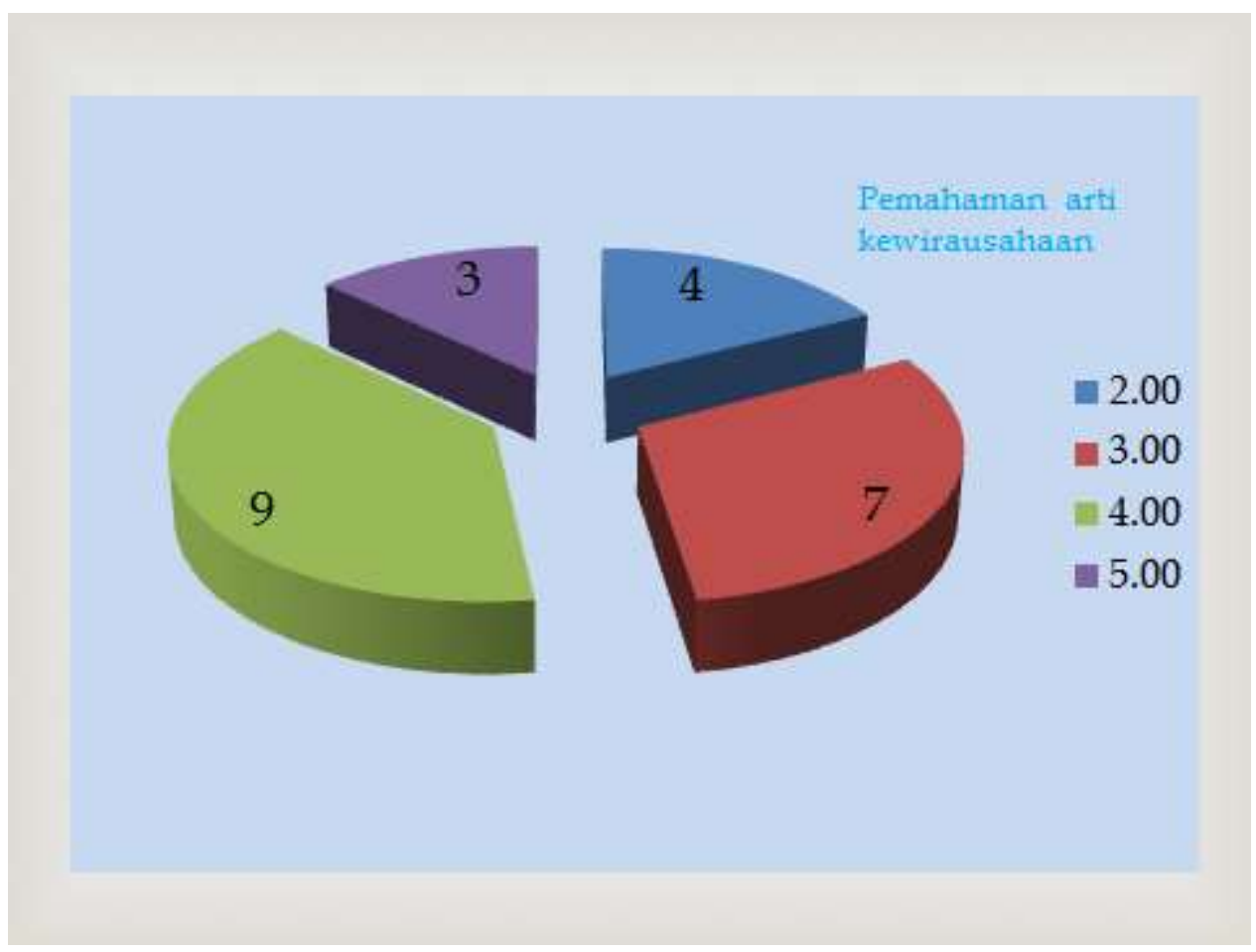

Berdasarkan tabel di atas, peserta yang sangat paham arti kewirausahaan sebesar $13,0 \%$, peserta paham sebesar $39,1 \%$ dan peserta cukup paham 30,4\% sedangkan yang tidak paham $17,4 \%$.

2. Apakah saudara paham Agama meminta kita untuk usaha (bisnis), terkait pertanyaan ini maka peserta menjawab seperti terlihat dalam table di bawah ini : 
Tabel 7. Wirausaha 2

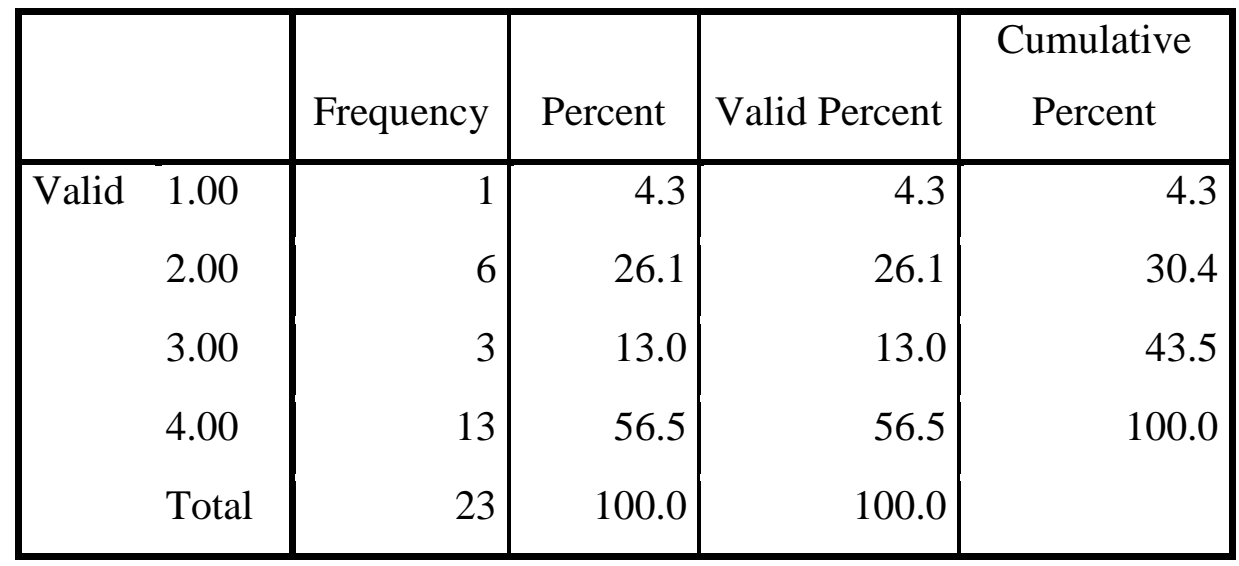

Sumber : Kuesioner, data diolah

\section{Pemahamanttg Agams \\ meminta kita untuk.}

tusaha

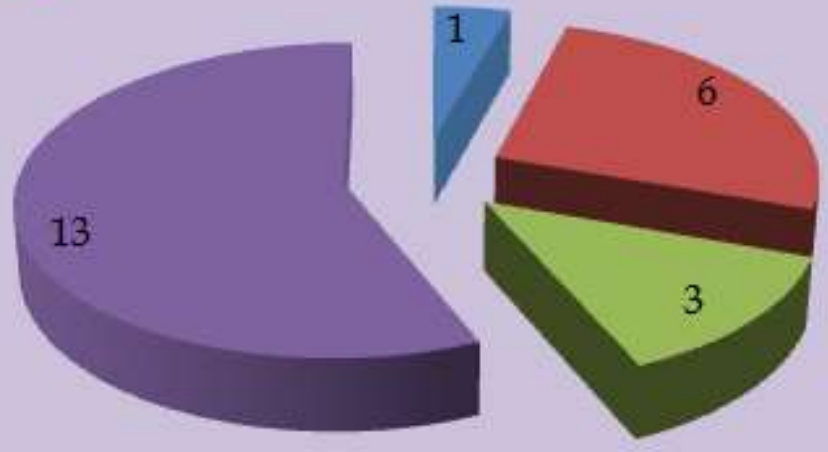

1.00

2.00

3.00

4.00

Berdasarkan tabel di atas, peserta yang paham Agama meminta kita untuk usaha (bisnis) sebesar 56,5\%, peserta cukup paham sebesar $13,0 \%$ dan peserta tidak paham $26,1 \%$ sedangkan yang tidak paham $4,3 \%$.

3. Apakah saudara paham langkah awal memulai usaha ? terkait pertanyaan ini maka peserta menjawab seperti terlihat dalam table di bawah ini : 
Tabel 8. Wirausaha 3

\begin{tabular}{|r|r|r|r|r|}
\hline & Frequency & Percent & Valid Percent & $\begin{array}{c}\text { Cumulative } \\
\text { Percent }\end{array}$ \\
\hline Valid 2.00 & 9 & 39.1 & 39.1 & 39.1 \\
& 3.00 & 13.0 & 13.0 & 52.2 \\
4.00 & 11 & 47.8 & 47.8 & 100.0 \\
Total & 23 & 100.0 & 100.0 & \\
\hline
\end{tabular}

Sumber : Kuesioner, data diolah

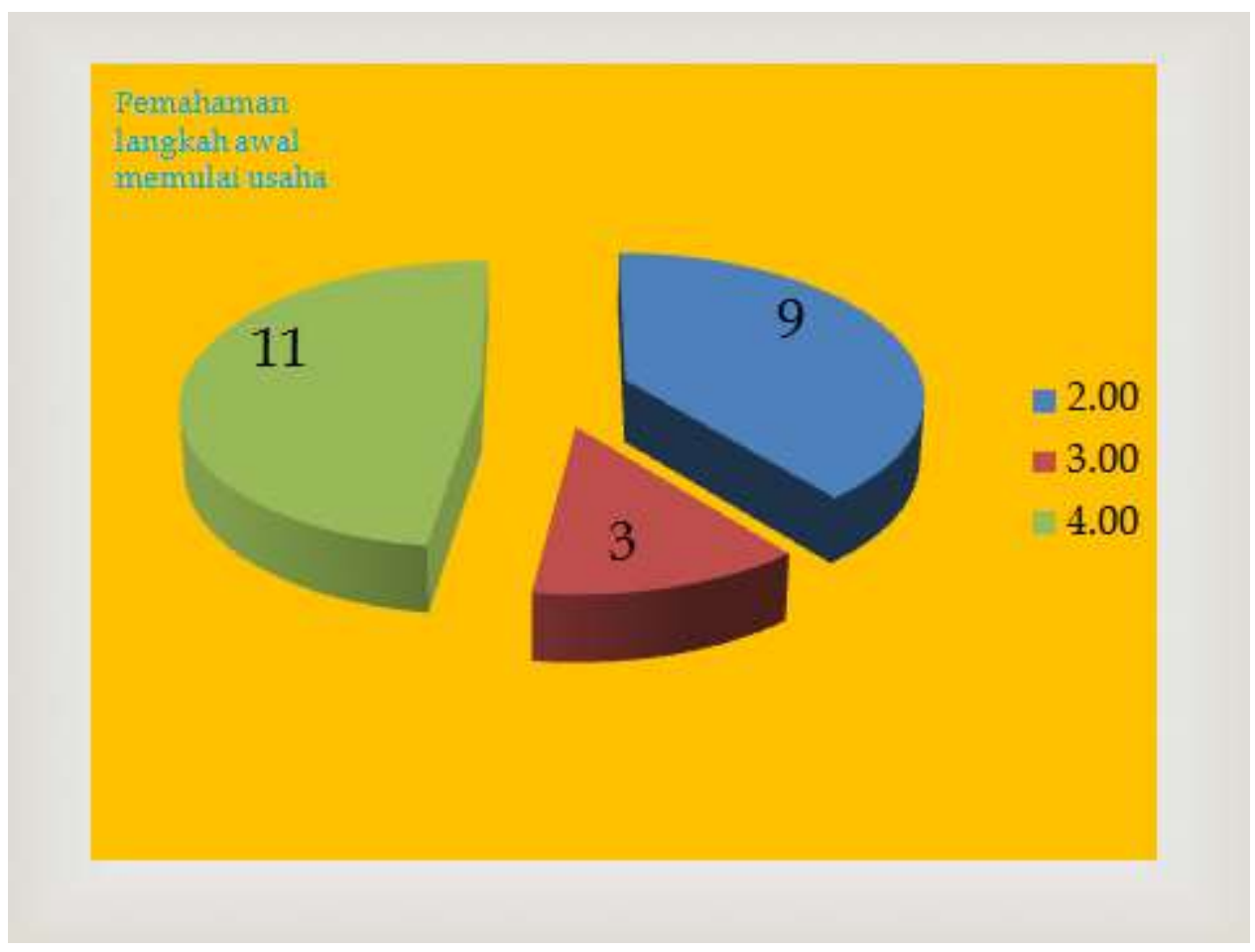

Berdasarkan tabel di atas, peserta yang paham langkah awal memulai usaha sebesar $47,8 \%$, peserta cukup paham sebesar $13,0 \%$ dan peserta tidak paham $39,1 \%$.

4. Apakah saudara paham cara menambah modal usaha ? terkait pertanyaan ini maka peserta menjawab seperti terlihat dalam table di bawah ini : 
Tabel 9. Wirausaha 4

\begin{tabular}{|r|r|r|r|r|}
\hline & Frequency & Percent & Valid Percent & $\begin{array}{c}\text { Cumulative } \\
\text { Percent }\end{array}$ \\
\hline Valid 2.00 & 12 & 52.2 & 52.2 & 52.2 \\
& 3.00 & 13.0 & 13.0 & 65.2 \\
4.00 & 8 & 34.8 & 34.8 & 100.0 \\
Total & 23 & 100.0 & 100.0 & \\
\hline
\end{tabular}

Sumber : Kuesioner, data diolah

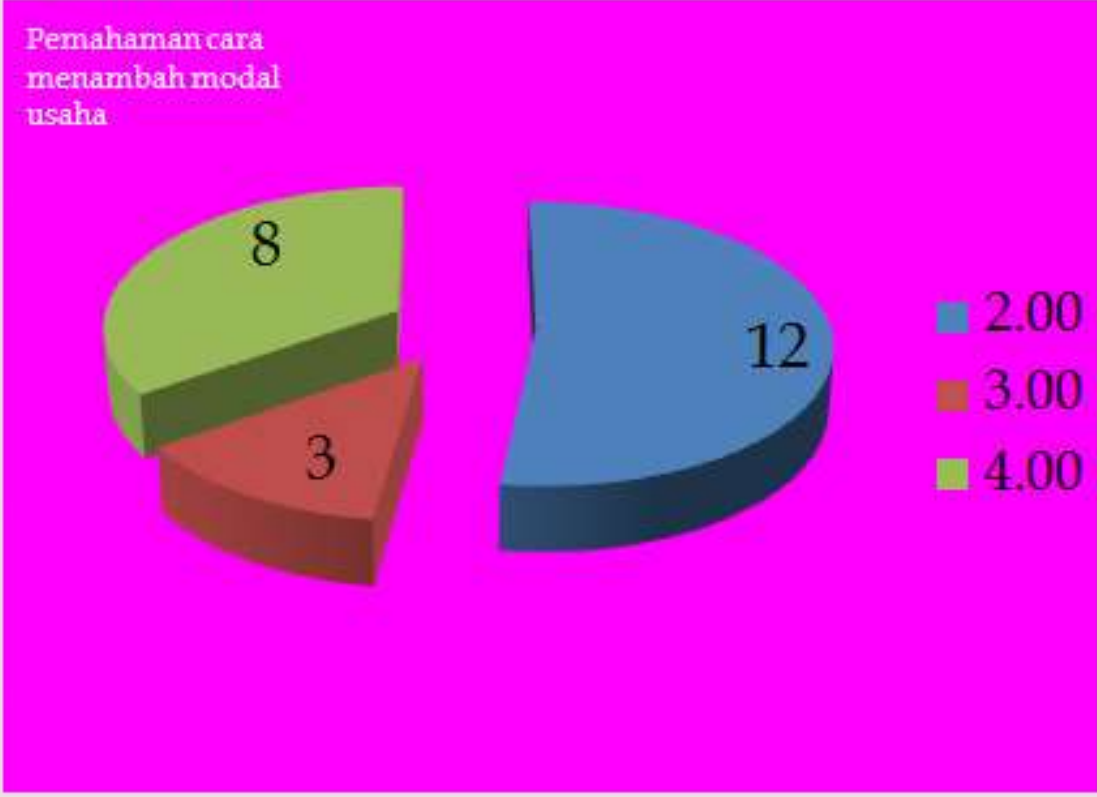

Berdasarkan tabel di atas, peserta yang paham cara menambah modal usaha sebesar $34,8 \%$, peserta cukup paham sebesar $13,0 \%$ dan peserta tidak paham $52,2 \%$.

5. Apakah saudara paham kendala-kendala yang muncul dalam mengembangkan usaha ? terkait pertanyaan ini maka peserta menjawab seperti terlihat dalam table di bawah ini : 
Tabel 10. Wirausaha 5

\begin{tabular}{|r|r|r|r|r|}
\hline & Frequency & Percent & Valid Percent & $\begin{array}{c}\text { Cumulative } \\
\text { Percent }\end{array}$ \\
\hline Valid 2.00 & 9 & 39.1 & 39.1 & 39.1 \\
& 3.00 & 13.0 & 13.0 & 52.2 \\
4.00 & 11 & 47.8 & 47.8 & 100.0 \\
& 23 & 100.0 & 100.0 & \\
\hline
\end{tabular}

Sumber : Kuesioner, data diolah

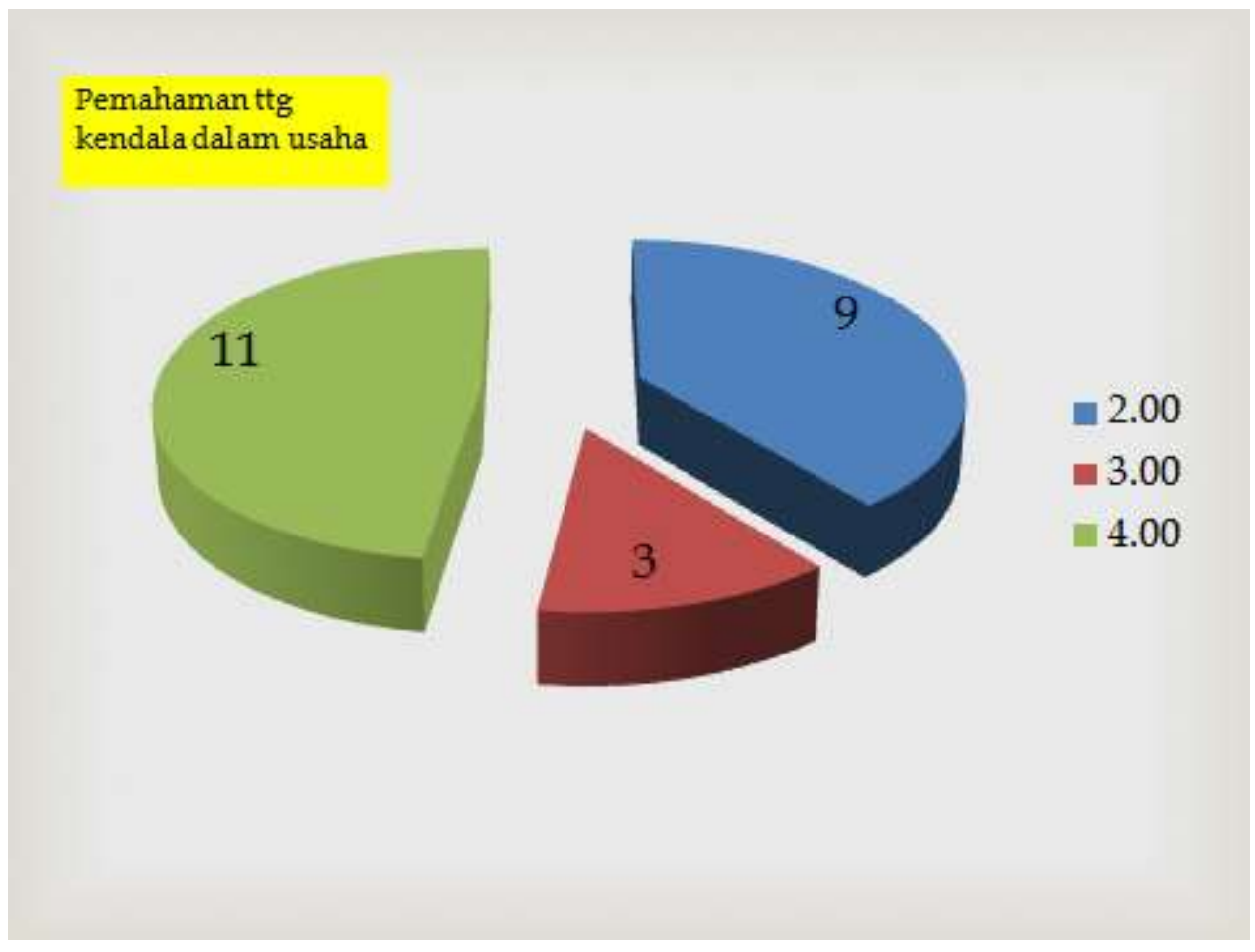

Berdasarkan tabel di atas, peserta yang paham kendala-kendala yang muncul dalam mengembangkan usaha sebesar $47,8 \%$, peserta cukup paham sebesar $13,0 \%$ dan peserta tidak paham $39,1 \%$.

\section{Aspek Kesehatan Lingkungan}

Kuesioner untuk Aspek Kesehatan Lingkungan memiliki 5 pertanyaan dengan hasil sebagai berikut : 
1. Apa saudara paham apa yang dimaksud dengan sampah? terkait pertanyaan ini maka peserta menjawab seperti terlihat dalam table di bawah ini :

Tabel 11. Kesehatan Lingkungan 1

\begin{tabular}{|r|r|r|r|r|}
\hline & Frequency & Percent & Valid Percent & $\begin{array}{c}\text { Cumulative } \\
\text { Percent }\end{array}$ \\
\hline Valid 2.00 & 4 & 17.4 & 17.4 & 17.4 \\
& 2 & 8.7 & 8.7 & 26.1 \\
4.00 & 14 & 60.9 & 60.9 & 87.0 \\
5.00 & 3 & 13.0 & 13.0 & 100.0 \\
Total & 23 & 100.0 & 100.0 & \\
\hline
\end{tabular}

Sumber : Kuesioner, data diolah

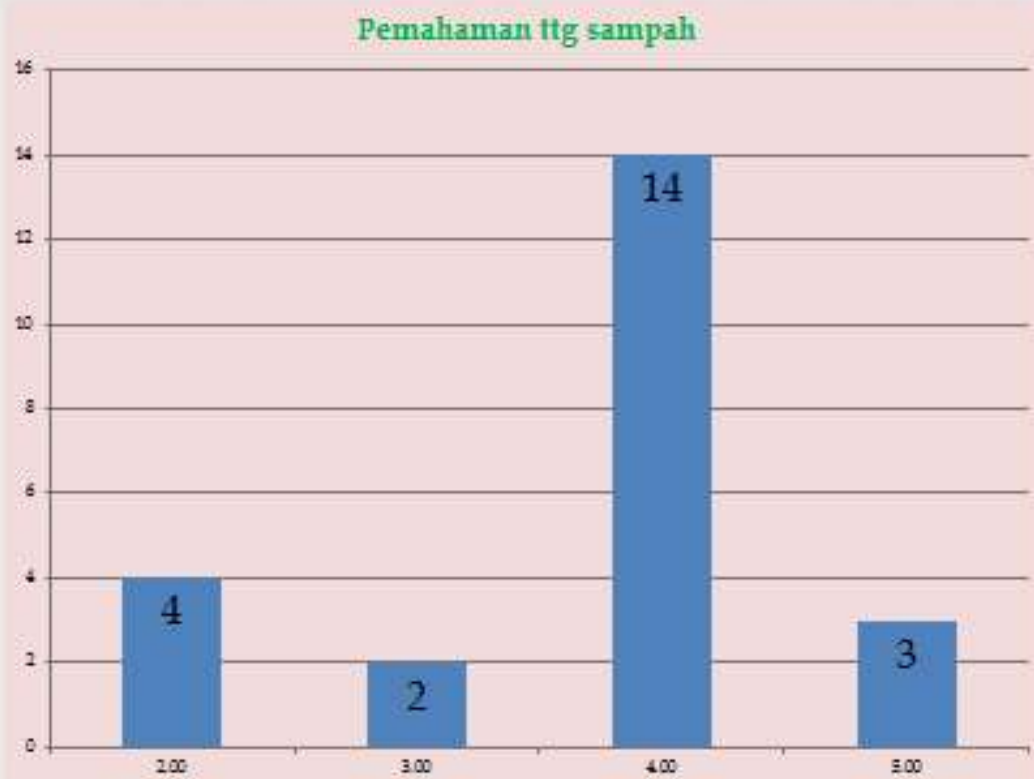

Berdasarkan tabel di atas, peserta yang paham apa yang dimaksud dengan sampah sebesar $60,9 \%$, peserta sangat paham sebesar $13,0 \%$ dan peserta cukup paham $8,7 \%$ serta peserta tidak paham sebesar $17,4 \%$. 
2. Apa saudara paham bahwa sampah membahayakan lingkungan hidup manusia? terkait pertanyaan ini maka peserta menjawab seperti terlihat dalam table di bawah ini :

Tabel 12. Kesehatan Lingkungan 2

\begin{tabular}{|c|c|c|c|c|c|}
\hline & & Frequency & Percent & Valid Percent & $\begin{array}{c}\text { Cumulative } \\
\text { Percent }\end{array}$ \\
\hline \multirow[t]{5}{*}{ Valid } & 1.00 & 1 & 4.3 & 4.3 & 4.3 \\
\hline & 3.00 & 5 & 21.7 & 21.7 & 26.1 \\
\hline & 4.00 & 9 & 39.1 & 39.1 & 65.2 \\
\hline & 5.00 & 8 & 34.8 & 34.8 & 100.0 \\
\hline & Total & 23 & 100.0 & 100.0 & \\
\hline
\end{tabular}

Sumber : Kuesioner, data diolah

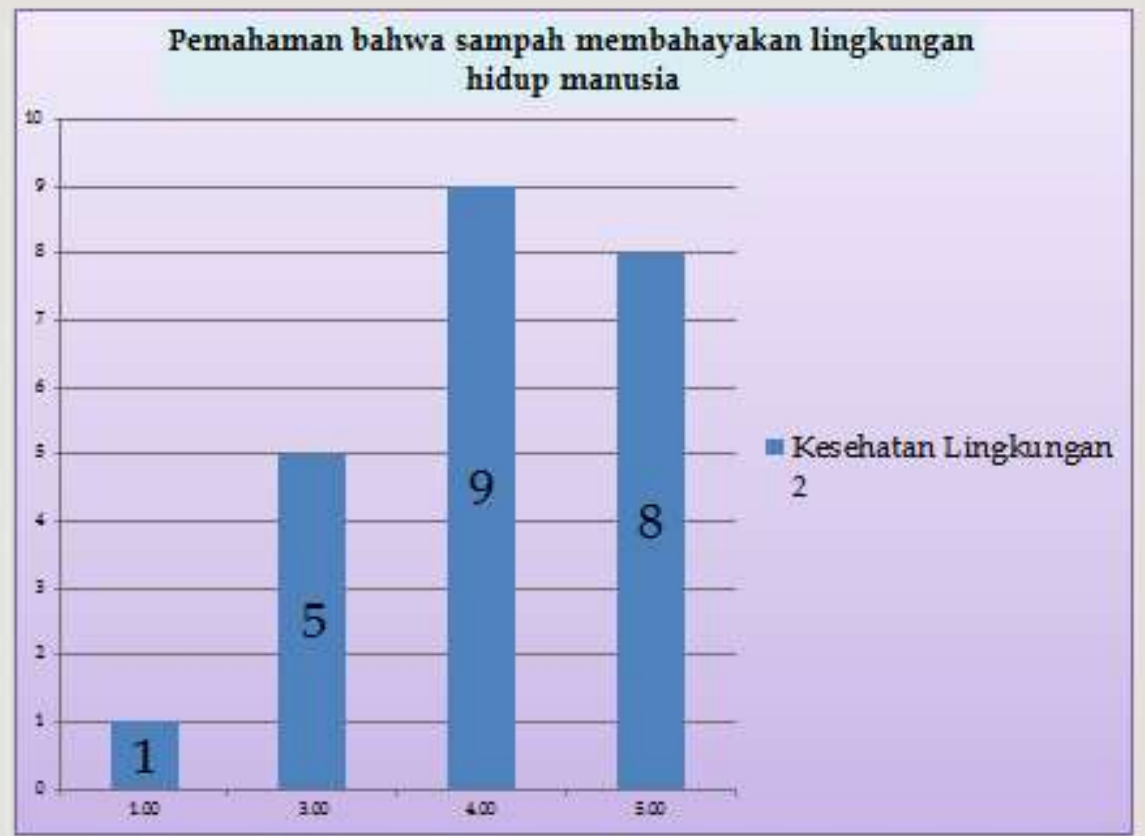

Berdasarkan tabel di atas, peserta yang paham sampah membahayakan lingkungan hidup manusia sebesar $39,1 \%$, peserta sangat paham sebesar 34,8 $\%$ dan peserta cukup paham $21,7 \%$ serta peserta sangat tidak paham sebesar $4,3 \%$. 
3. Apa saudara paham bahwa sampah dapat memberi manfaat bagi manusia ? terkait pertanyaan ini maka peserta menjawab seperti terlihat dalam table di bawah ini :

Tabel 13. Kesehatan Lingkungan 3

\begin{tabular}{|r|r|r|r|r|}
\hline & Frequency & Percent & Valid Percent & $\begin{array}{c}\text { Cumulative } \\
\text { Percent }\end{array}$ \\
\hline Valid 2.00 & 8 & 34.8 & 34.8 & 34.8 \\
3.00 & 1 & 4.3 & 4.3 & 39.1 \\
4.00 & 13 & 56.5 & 56.5 & 95.7 \\
5.00 & 1 & 4.3 & 4.3 & 100.0 \\
Total & 23 & 100.0 & 100.0 & \\
\hline
\end{tabular}

Sumber : Kuesioner, data diolah

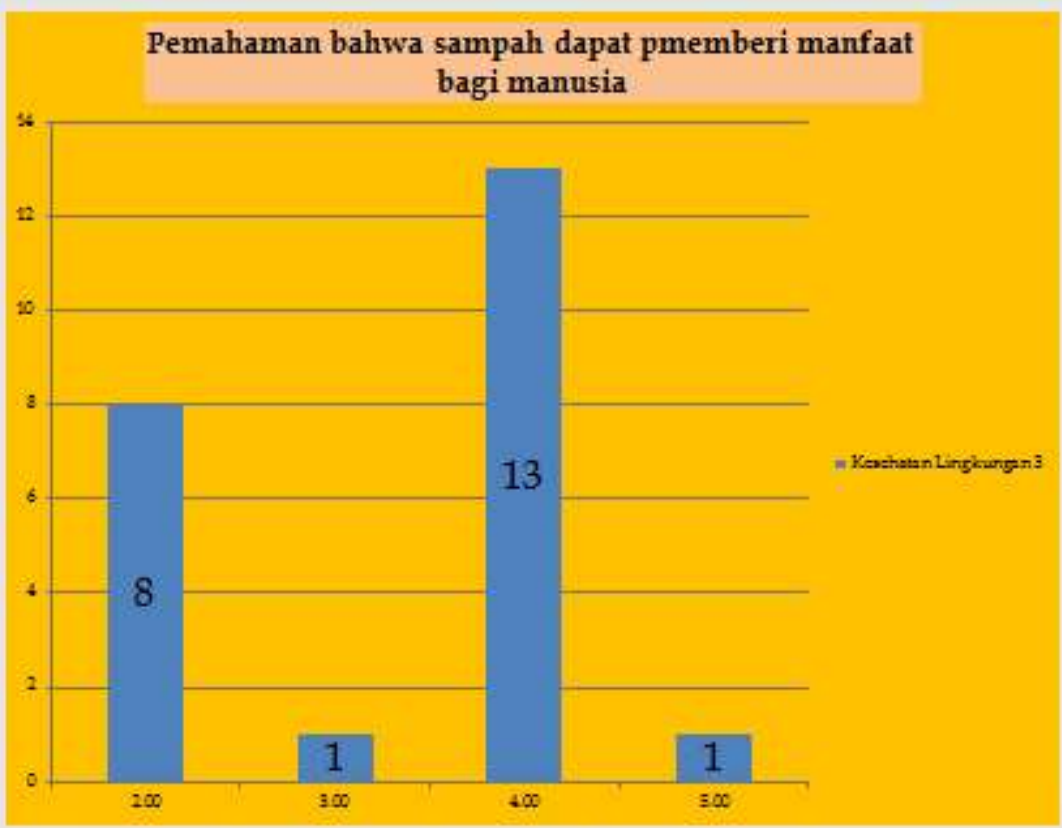

Berdasarkan tabeL di atas, peserta yang paham sampah dapat memberi manfaat bagi manusia sebesar $56,5 \%$, peserta sangat paham sebesar $4,3 \%$ dan peserta cukup paham $4,3 \%$ serta peserta tidak paham sebesar $34,8 \%$.

4. Apa saudara paham bahwa sampah dapat dikelola dengan baik? terkait pertanyaan ini maka peserta menjawab seperti terlihat dalam tabel di bawah ini : 
Tabel 14. Kesehatan Lingkungan 4

\begin{tabular}{|rr|r|r|r|r|}
\hline & Frequency & Percent & Valid Percent & $\begin{array}{c}\text { Cumulative } \\
\text { Percent }\end{array}$ \\
\hline Valid 1.00 & 2 & 8.7 & 8.7 & 8.7 \\
& 2.00 & 1 & 4.3 & 4.3 & 13.0 \\
3.00 & 4 & 17.4 & 17.4 & 30.4 \\
4.00 & 14 & 60.9 & 60.9 & 91.3 \\
5.00 & 2 & 8.7 & 8.7 & 100.0 \\
Total & 23 & 100.0 & 100.0 & \\
\hline
\end{tabular}

Sumber : Kuesioner, data diolah

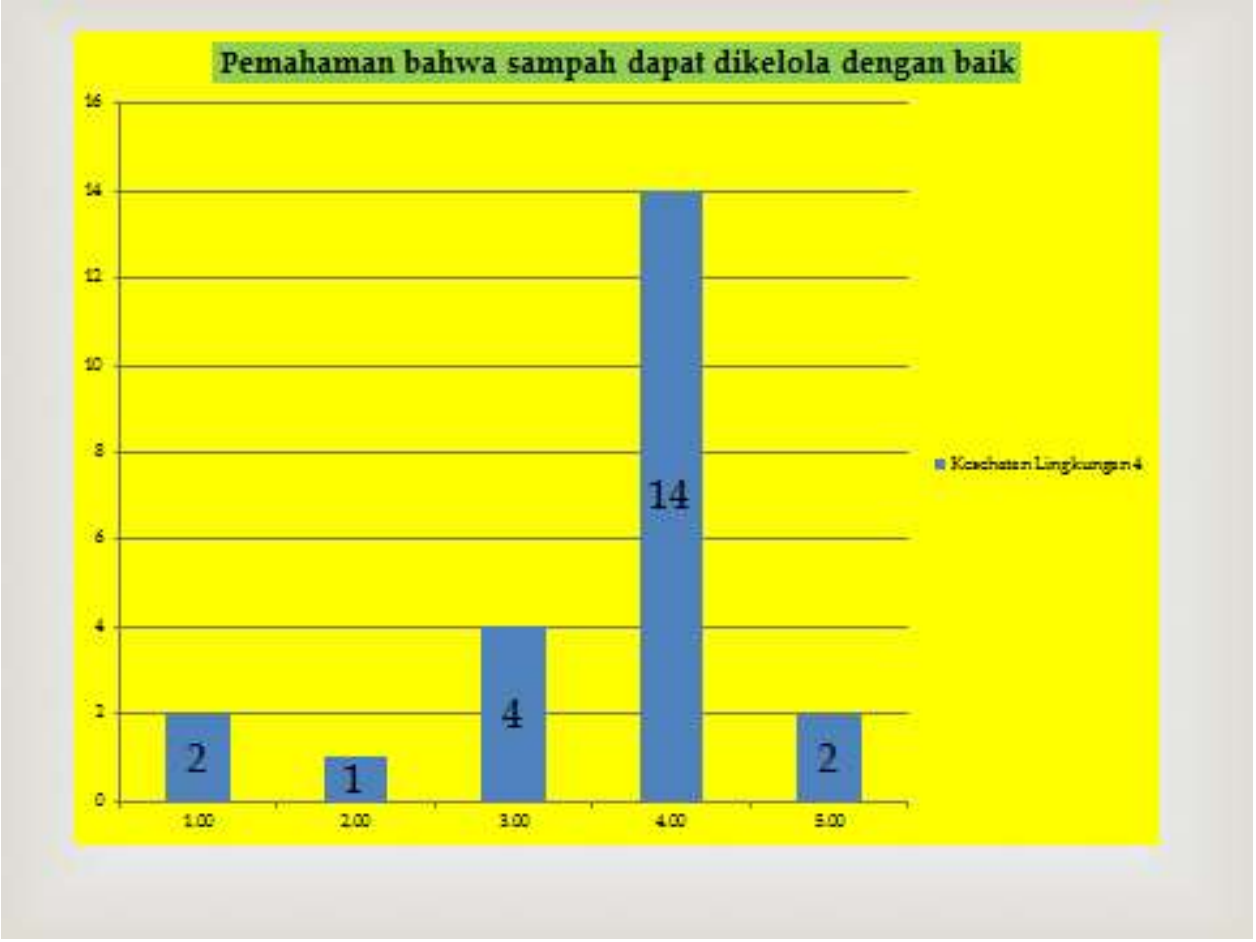

Berdasarkan tabel di atas, peserta yang paham sampah dapat dikelola dengan baik sebesar $60,9 \%$, peserta sangat paham sebesar $8,7 \%$ dan peserta cukup paham $17,4 \%$ serta peserta tidak paham sebesar $4,3 \%$. Sedangkan peserta yang tidak paham sebesar

5. Apa saudara paham bahwa sampah dapat menghemat belanja rumah tangga ? terkait pertanyaan ini maka peserta menjawab seperti terlihat dalam table di bawah ini : 
Tabel 14. Kesehatan Lingkungan 5

\begin{tabular}{|r|r|r|r|r|}
\hline & Frequency & Percent & Valid Percent & $\begin{array}{c}\text { Cumulative } \\
\text { Percent }\end{array}$ \\
\hline Valid 2.00 & 11 & 47.8 & 47.8 & 47.8 \\
& 3.00 & 13.0 & 13.0 & 60.9 \\
4.00 & 9 & 39.1 & 39.1 & 100.0 \\
Total & 23 & 100.0 & 100.0 & \\
\hline
\end{tabular}

Sumber : Kuesioner, data diolah

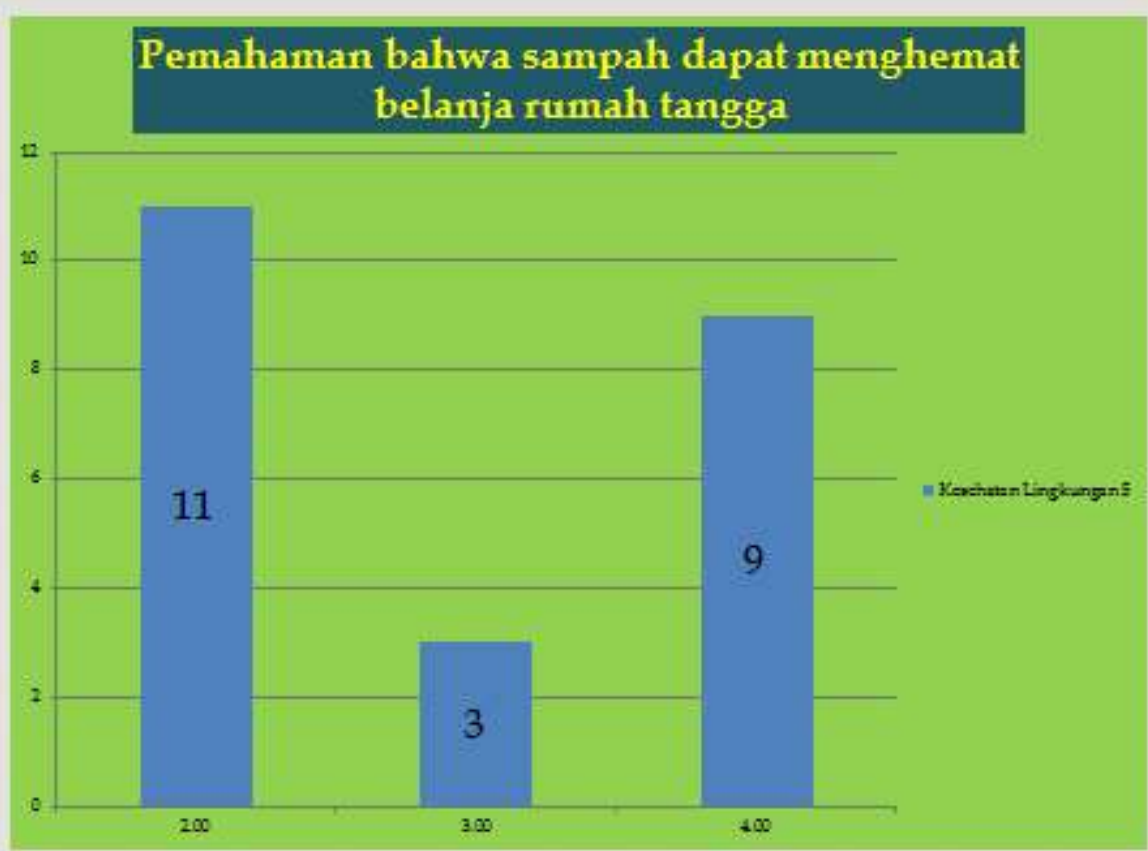

Berdasarkan tabel di atas, peserta yang paham sampah dapat menghemat belanja rumah tangga sebesar $39,1 \%$, peserta cukup paham $13,0 \%$ serta peserta tidak paham sebesar $47,8 \%$.

\section{MODEL PEMBERDAYAAN}

Berdasarkan hasil diskusi dan wawancara dengan aparat desa Tanjungpasir dan beberapa warga serta didukung hasil kuesioner, maka masyarakat pesisir Tanjung Pasir perlu didampingi dalam upaya pemberdayaan menuju sadar hukum, sadar wira usaha dan sadar lingkungan. Perlu uluran tangan dan perhatian dari 
pemerintah, kampus dan LSM serta partisipasi aktif warga sendiri. Model pemberdayaan yang dihasilkan dapat digambarkan sebagai berikut :

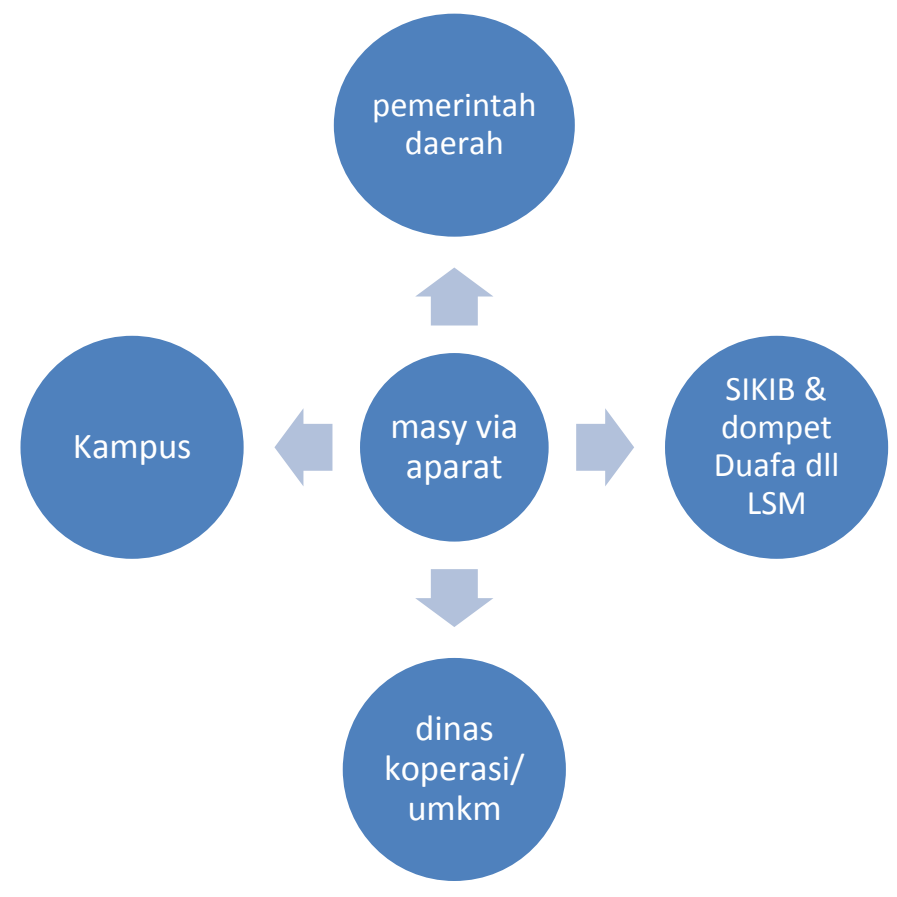

\section{KESIMPULAN}

Berdasarkan uraian pembahasan di atas, dapat disimpulkan sebagai berikut:

1. Dalam upaya memberdayakan masyarakat Tanjung Pasir terkait upaya menumbuhkembangkan sadar hukum, sadar wira usaha, dan sadar lingkungan perlu didampingi dan diberikan uluran tangan serta perhatian dari pemerintah, kampus dan LSM serta partisipasi aktif warga sendiri.

2. Model pemberdayaan yang tepat untuk diterapkan pada masyarakat pesisir, adalah dengan kerjasama sinergitas antara warga masyarakat, aparat desa, dinas terkait serta LSM yang peduli serta bantuan kampus. Pemberdayaan pada tahap awal ini penting untuk menumbuhkan kesadaran tentang hukum, wira usaha, dan lingkungan, mengingat pada dasarnya pemahaman warga masyarakat terhadap pengelolaan sampah sudah bagus, wira usaha cukup paham, namun pemahaman tentang hukum sangat rendah. 


\section{DAFTAR PUSTAKA}

Komite Ekonomi Nasional. Prospek Ekonomi Indonesia 2012: Terus Tumbuh di Tengah Ketidakpastian Global. 2012.

Kuncoro, Mudrajad. Ekonomi Pembangunan, Teori, Masalah dan Keajaiban. Yogyakarta: UPP STM YKPN, 2006.

Purwaningsih, Endang. "Model Pemberdayaan Indigenous People dalam rangka Perlindungan Hukum terhadap Traditional Knowledge Indonesia," Laporan Penelitian HIKOM peneliti 2012. Jakarta: Dirjen Dikti, DP2M, 2012.

Purwaningsih, Endang. Hukum Bisnis. Jakarta: Ghalia Yudistira, 2009.

Purwaningsih, Endang. "Model Pemberdayaan Indigenous People dalam rangka Perlindungan Hukum terhadap Traditional Knowledge Indonesia," Laporan Penelitian HIKOM peneliti 2012, Jakarta: Dirjen Dikti, DP2M, 2012.

Soenyono. Pemberdayaan Masyarakat Miskin, Surabaya: Jenggala Pustaka Utama, 2011.

Tambunan, Tulus TH. Perekonomian Indonesia, Beberapa Permasalahan Penting, Jakarta: Ghalia Indonesia, 2003. 